\title{
SEEDS
}

Surrey Energy Economics

SURREY

Discussion paper Series

ENERGY

ECONOMICS

Centre

\section{Industrial Electricity Demand for Turkey : A Structural Time Series Analysis}

\author{
Zafer Dilaver and Lester C Hunt
}

September 2010

SEEDS 129 ISSN 1749-8384
Department of Economics University of Surrey 
The Surrey Energy Economics Centre (SEEC) consists of members of the Department of Economics who work on energy economics, environmental economics and regulation. The Department of Economics has a long-standing tradition of energy economics research from its early origins under the leadership of Professor Colin Robinson. This was consolidated in 1983 when the University established SEEC, with Colin as the Director; to study the economics of energy and energy markets.

SEEC undertakes original energy economics research and since being established it has conducted research across the whole spectrum of energy economics, including the international oil market, North Sea oil \& gas, UK \& international coal, gas privatisation \& regulation, electricity privatisation \& regulation, measurement of efficiency in energy industries, energy \& development, energy demand modelling \& forecasting, and energy \& the environment.

SEEC research output includes SEEDS - Surrey Energy Economic Discussion paper Series (details at www.seec.surrey.ac.uk/Research/SEEDS.htm) as well as a range of other academic papers, books and monographs. SEEC also runs workshops and conferences that bring together academics and practitioners to explore and discuss the important energy issues of the day.

SEEC also attracts a large proportion of the department's PhD students and oversees the MSc in Energy Economics \& Policy. Many students have successfully completed their MSc and/or PhD in energy economics and gone on to very interesting and rewarding careers, both in academia and the energy industry.

Enquiries:

Director of SEEC and Editor of SEEDS:

Lester C Hunt

SEEC,

Department of Economics, University of Surrey, Guildford GU2 7XH, UK.

Tel: $\quad$ +44 (0)1483 686956

Fax: $\quad$ +44 (0)1483689548

Email: L.Hunt@surrey.ac.uk

www.seec.surrey.ac.uk 


\title{
Surrey Energy Economics Centre (SEEC) Department of Economics University of Surrey
}

\author{
SEEDS 129
}

ISSN 1749-8384

\author{
INDUSTRIAL ELECTRICITY DEMAND \\ FOR TURKEY: A STRUCTURAL \\ TIME SERIES ANALYSIS \\ Zafer Dilaver and Lester C Hunt
}

September 2010

This paper may not be quoted or reproduced without permission. 


\begin{abstract}
This research investigates the relationship between Turkish industrial electricity consumption, industrial value added and electricity prices in order to forecast future Turkish industrial electricity demand. To achieve this, an industrial electricity demand function for Turkey is estimated by applying the structural time series technique to annual data over the period 1960 to 2008. In addition to identifying the size and significance of the price and industrial value added (output) elasticities, this technique also uncovers the electricity Underlying Energy Demand Trend (UEDT) for the Turkish industrial sector and is, as far as is known, the first attempt to do this. The results suggest that output and real electricity prices and a UEDT all have an important role to play in driving Turkish industrial electricity demand. Consequently, they should all be incorporated when modelling Turkish industrial electricity demand and the estimated UEDT should arguably be considered in future energy policy decisions concerning the Turkish electricity industry. The output and price elasticities are estimated to be 0.15 and -0.16 respectively, with an increasing (but at a decreasing rate) UEDT and based on the estimated equation, and different forecast assumptions, it is predicted that Turkish industrial electricity demand will be somewhere between 97 and 148 TWh by 2020 .
\end{abstract}

JEL Classifications: C22; Q41; Q47; Q48.

Key Words: Turkish Industrial Electricity Demand; Energy Demand Modelling and Forecasting; Structural Time Series Model (STSM); Future Scenarios. 


\title{
Industrial Electricity Demand for Turkey: A Structural Time Series Analysis*
}

\author{
Zafer Dilaver $^{\#}$ and Lester C Hunt \\ Surrey Energy Economics Centre (SEEC), \\ Department of Economics, \\ University of Surrey, \\ Guildford, \\ GU2 7XH, \\ Surrey, UK
}

\section{Introduction}

This paper investigates the relationship between Turkish industrial electricity consumption, industrial value added (output) and electricity prices in order to forecast future Turkish industrial electricity demand. To achieve this, an industrial electricity demand function for Turkey is estimated by applying the structural time series technique to annual data over the period 1960 to 2008. During this period, the Turkish economy experienced a number of economic crises and economic policy changes. In particular, there were four serious and long lasting economic crises in 1978-1981, 1988-1989, 1994 and 1998-2002; in addition to the three mid size, and relatively short lasting, economic crises in 1969, 1982, and 1991 (Kazgan, 2002).

As part of the response to these continuing problems, the Turkish government responded in the 1960s and 1970s by implementing an industrialization strategy based upon import substitution. This resulted in significantly higher and more stable growth rates until the late

\section{*Acknowledgements}

We are grateful for the comments by two anonymous referees on a previous draft of the paper and thank them for helping to improve the paper. The authors are, of course, responsible for all errors and omissions.

\footnotetext{
${ }^{\#}$ Corresponding Author

Email Address, $\underline{\text { Z.Dilaver@surrey.ac.uk. }}$
} 
1970s. However, the Turkish government's decision not to allow the increase in the cost of oil imports due to the oil price hikes of the early and late 1970 s to permeate through the economy and hence shoulder the true economic 'burden' of high oil prices resulted in balance of payments problems and an increase in the budget deficit. This led to the worst political instability in Turkish history, when inflation reached $64 \%$ with a balance of payments 'crisis' in 1979, with GDP declining in both 1979 and 1980. It was following this period that Turkey adopted export-oriented industrialization policies (Taymaz and Yilmaz, 2007).

Not surprisingly, these crises and policy changes affected both industrial output and industrial electricity consumption. As highlighted above, before 1980 the Turkish economy was inward looking with an import-substituting industrialization strategy; whereas, after 1980 this changed to an export oriented industrialization strategy. Therefore, before 1980 the Turkish industrial sector was more vulnerable to domestic shocks whereas after 1980 it became more vulnerable to external shocks such as the Gulf War and the global economic crisis. However despite this volatility, Turkish industrial electricity consumption increased by an average of about $8 \frac{1}{2} \%$ per year from about $1 \frac{1}{2}$ TWh to just over 72 TWh over the period 1960 to 2008 (IEA, 2010). This high growth rate of industrial electricity consumption would appear, according to Bakirtas et al. (2000) to be mainly a result of the increasing number of applications of energy intensive technologies in the Turkish industrial sector.

Although Turkish industrial electricity consumption generally followed an upward trend over the period 1960 to 2008 some falls did occur; consistent with the economic crises, namely just under $4 \%$ in 1991, just under $2.4 \%$ in 2001, and a very marginal fall in 1994 (IEA, 2010). In 2008, industrial electricity consumption accounted for $45 \%$ of total Turkish electricity consumption, down from just above two thirds in 1960. Although the share of industrial 
electricity consumption in total electricity consumption diminished, it still has a significant weight in overall electricity consumption (IEA, 2010). On the other hand industrial value added increased from just under 9 billion (2005 constant YTL) to just under 175 billion (2005 constant YTL) representing an average annual increase of just under $6 \frac{1}{2} \%$ for the period 1960 to 2008 as illustrated in Figure 1 (World Bank, 2010). As discussed above, the effect of the changing international oil price and energy prices in general were not felt directly throughout the economy, including the industrial sector, given the regulation of energy prices by the Turkish government. And, despite the Electricity Market Law No: 4628, introduced in 2001 with the aim of creating a liberalized market structure, Turkish electricity prices were mainly regulated by the government over the whole of the 1960 to 2008 period.

Figure 1: Industrial Value Added, Industrial Electricity Consumption, Industrial Electricity Prices Growth Rates 1960-2008

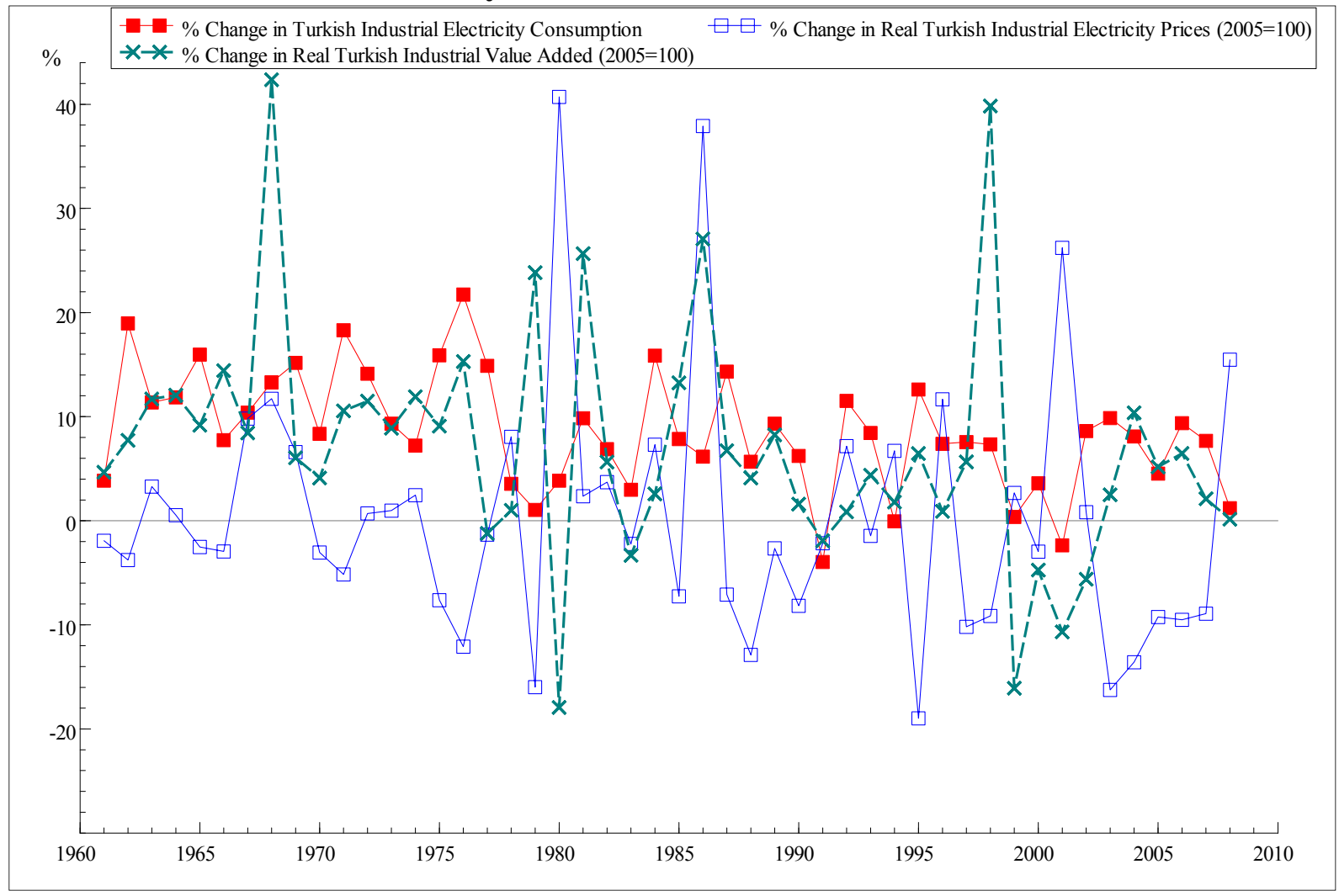


Econometric modelling of energy behaviour helps understand the past, thus better preparing policy makers for possible future outcomes and opportunities, such as the financing of the development of necessary natural resources, the utilization of new technologies, evaluation of energy generating capacity, etc. (McVeigh and Mordue, 1999). Thus, for sustainable economic growth and a healthy industrial sector, robust reliable demand forecasts of Turkish industrial electricity demand are vital for the development of appropriate energy policies to support the industrial sector. The aim of this study therefore is to investigate how the structural time series methodology performs in terms of modelling Turkish industrial electricity demand, estimating the key output and price elasticities, and forecasting the future industrial electricity demand.

The motivation and justification for this study is twofold. Firstly, the modern approach of structural time series modelling is utilised, focusing on the economic and exogenous factors of industrial electricity demand function by investigating the relationship between industrial electricity consumption, price, and output and an underlying energy demand trend. This therefore is, as far is known, the first study that allows for a stochastic industrial Underlying Energy Demand Trend (UEDT) for Turkey to be estimated. Secondly, the estimated model is used to forecast industrial electricity demand, which is compared to past Turkish industrial energy demand projections, since it is hypothesised that a model estimated using the structural time series methodology will outperform these previous forecasts. That is, the use of the structural times series modelling methodology to underpin the forecast is arguably a solution to the shortcomings of previous 'unsuccessful' forecasts; the forecasts being essential for evaluating policies and strategies in order to achieve Energy Security. Therefore, given the importance of the industrial sector, this study contributes to the development of Turkish energy policy and the strategy to ensure future Turkish energy security. Additionally 
more accurate forecast results are vital for Turkish electricity generating and distribution companies in order to establish their long-term investment decisions.

In the second section previous Turkish energy demand forecast studies are discussed, in the third section, a summary of the associated literature is examined. The fourth section discusses the methodology employed in this study, with the data and results presented in the fifth section. The sixth section presents forecasts and scenarios with a summary and discussion of the consequences of the study discussed in the final section.

\section{Discussion of previous energy demand forecast studies in Turkey}

Studies before the 1970s that directly focused on analyzing Turkish Electricity demand are very limited, being generally carried out by governmental institutions with their own approaches, namely the State Planning Organization (SPO), the State Institute of Statistics (SIS) and the Ministry of Energy and Natural Resources (MENR). Although some research in those institutions tried to apply mathematical modelling techniques to analyze energy demand in the late 1970s, these methods were not used in official energy planning until 1984. Before 1984, national energy policy was shaped by the forecasts of the SPO in which they employed various simple best-fit curves (Ediger and Tatlidil, 2002).

The MENR utilized different models in order to determine energy demand functions and to make future projections. For instance, 'Balance' models that are non-linear equilibrium models that match the energy demand with available resources and technologies and 'Impact' models that focus on the relation between energy consumption and its interaction with the environment were employed in the framework of Energy and Power Evaluation Program 
(ENPEP). Both models were used for the long-term supply and demand projections between 1981 and 1985. The MENR began to use the simulation models namely MAED, WASP III, and EFOM-12 C Mark. MAED (Model for Analysis of Energy Demand) and WASP III (Wien Automatic System Planning) were originally developed by the International Atomic Energy Agency (IAEA) and the energy demand model EFOM-12 C Mark (Energy Flow Optimization Model) was developed by the commission of the European Union starting from 1984 (Ediger and Tatlidil, 2002).

At the same time, SPO also developed its own models based on sectoral energy demand for different consumer groups, subgroups and finally the mathematical models were developed for each sub group by regression. On the other hand, the SIS explored the relationship between demographic factors and economic parameters with energy demand in its models. Both of the models explored by SIS and SPO verified the relationship between energy demand and GDP (Ediger and Tatlidil, 2002).

The previous forecast and energy modelling studies above used different kinds of approaches, but the main motivation of all those studies was to provide better energy and electricity planning tools for policy makers for sustainable economic growth. However, the previous forecast studies such as those produced from MAED, WASP III, and EFOM-12 C Mark, always predicted much higher demand levels than the actual outturn. Moreover, Keleş (2005) argues that the policies adopted based upon these unsuccessful forecasts resulted in a significant proportion of electricity generation capacity remaining idle, transformed the Turkish economy to be more dependent on imported primary energy resources, prevented energy markets liberalization, and resulted in high electricity prices. Hence, as explained above, a key motivation for this paper is to develop a more robust model of Turkish energy 
demand in order to produce more reliable forecasts and scenarios for future industrial electricity demand.

\section{Literature Review}

In this section key literature is discussed with the focus on 1) previous Turkish energy demand studies; 2) the conceptual issues about technical progress and the UEDT; and 3) previous energy demand studies using the Structural Time Series Model (STSM), given no previous studies have been undertaken using the structural time series modelling approach for Turkey.

\subsection{Turkish energy modelling studies}

There was a large increase in the number of Turkish energy modelling studies after the late 1990s and they can be divided into three main groups. In the first group, the focus is on investigating the causality between energy consumption and economic variables (termed 'Causality Studies' below). In the second group, the focus is on identifying the relationship and the magnitude of the key relationships (mainly the elasticities) between economic variables and energy consumption (termed 'Relationship Studies' below). And in the third group, the aim is to forecast future energy demand using a number of different approaches (termed 'Forecast Studies' below). However, there are very few past studies that focus on the industrial sector; consequently, these general Turkish studies are briefly reviewed below in a general context with a detailed summary presented in Table 1, followed by a more detailed discussion of the few studies that focus explicitly on modelling Turkish industrial electricity consumption. 
- Causality Studies: The focus is whether statistical causality (usually defined as Granger Causality) between energy consumption and economic variables, such as GDP exists. These include, Erdal, et al. (2008), Karanfil (2008), Erbaykal (2008), Jobert and Karanfil (2007), Soytas and Sari (2007), Lise and Montfront (2007), Altinay and Karagol (2005) who applied different techniques including simple Granger Causality, Vector Auto Regression (VAR), Instantaneous Causality, Bonds Testing Cointegration, Johansen Cointegration, Pair-wise Granger Causality, Error Variance Decomposition, Impulse Response and Vector Error Correction Model (VECM). However, whatever techniques were applied, all studies in this group aimed to determine whether causality between energy consumption and certain economic variables exists plus the direction of the causality.

- Relationship Studies: The focus is generally on identifying the relationship between energy, activity, and price variables and the magnitude of the relationship. These include Bakirtas et al. (2000), Erdogdu (2007), and Halicioglu (2007) who employed different methods such as Engle-Granger two-step procedure, Auto Regressive Moving Average, Bonds Testing Cointegration and the Partial Adjustment Model, to estimate price and income elasticities for total Turkish electricity demand and residential electricity demand.

Bakirtas et al. (2000) found the long run income elasticity of total electricity demand to be 3.1 and the long run price elasticity of total electricity demand to be zero; i.e. not significantly different from zero. Whereas, Erdogdu (2007) 
found the long run income and price elasticity of total electricity demand to be 0.41 and -0.30 respectively. This compares to the 0.70 long run income elasticity of residential electricity demand and the -0.52 long run price elasticity of residential electricity demand found by Halicoglu (2007).

- Forecast Studies: Here the focus is on predicting future energy demand such as Ediger and Akar (2007), Hamzacebi (2007), Erdogdu (2007), Akay and Atak (2006), Ceylan and Ozturk (2004), Ozturk et al (2005) and Ediger and Tatlidil (2002). These studies used various methods including Univariate Cycle Analysis, Genetic Algorithm Approach, Grey Prediction with Rolling Mechanism, Auto Regressive Integrated Moving Average (ARIMA), and Artificial Neural Networks.

As far as is known, there is only one study, Soytas and Sari (2007), that focused on the relationship between economic activity and industrial electricity demand for Turkey. Using annual data for 1968 to 2002, employing cointegration Granger causality tests, Soytas and Sari (2007) explored the relationship between Turkish industrial value added and industrial electricity consumption, whilst accounting for labour and fixed investment. Whilst they found that all these variables are co-integrated, they found only uni-directional causality from electricity consumption to value added. However, arguably one criticism of this research is the failure of Soytas and Sari (2007) to include industrial electricity prices in the model, which might explain the results obtained, and hence the outcome arguably does not enlightening Turkish policy makers very much. 
Table 1: Summary of Turkish Energy Demand Studies Literature Review

\begin{tabular}{|c|c|c|c|}
\hline Reference & Focus of Study & Method & Summary \\
\hline $\begin{array}{l}\text { Erdal, et al. } \\
\quad \text { (2008) }\end{array}$ & $\begin{array}{l}\text { Energy } \\
\text { Consumption and } \\
\text { Growth }\end{array}$ & $\begin{array}{l}\text { Johansen } \\
\text { Cointegration, Pair- } \\
\text { wise Granger } \\
\text { causality }\end{array}$ & $\begin{array}{l}\text { Energy consumption and GNP are cointegrated and there is } \\
\text { bidirectional causality running from energy consumption and GNP } \\
\text { and vice versa. }\end{array}$ \\
\hline Karanfil (2008) & $\begin{array}{l}\text { Energy } \\
\text { Consumption, } \\
\text { Growth and } \\
\text { Unrecorded } \\
\text { Economy }\end{array}$ & VECM-VAR & $\begin{array}{l}\text { There is a long term equilibrium relationship between the } \\
\text { officially calculated GDP and energy consumption. However } \\
\text { when unrecorded economy is taken into account there is no } \\
\text { causality between energy consumption and GNP. }\end{array}$ \\
\hline Erbaykal (2008) & $\begin{array}{l}\text { Oil and Electricity } \\
\text { Consumption and } \\
\text { Economic Growth }\end{array}$ & $\begin{array}{l}\text { Bounds testing } \\
\text { Cointegration } \\
\text { approach }\end{array}$ & $\begin{array}{l}\text { Both electricity and oil consumption have a short term effect on } \\
\text { economic growth. }\end{array}$ \\
\hline $\begin{array}{l}\text { Soytas and Sari } \\
\text { (2007) }\end{array}$ & $\begin{array}{l}\text { Industrial } \\
\text { Electricity } \\
\text { Consumption }\end{array}$ & $\begin{array}{l}\text { Error Variance } \\
\text { Decomposition \& } \\
\text { Impulse Response }\end{array}$ & $\begin{array}{l}\text { Industrial Value added, industrial electricity consumption, labor } \\
\text { and fixed investment are cointegrated in long term, no significant } \\
\text { impact on each other in short term }\end{array}$ \\
\hline $\begin{array}{l}\text { Hamzacebi } \\
\text { (2007) }\end{array}$ & $\begin{array}{l}\text { Total and Sectoral } \\
\text { Electricity } \\
\text { Consumption }\end{array}$ & $\begin{array}{l}\text { Artificial Neural } \\
\text { Networks }\end{array}$ & $\begin{array}{l}\text { The total electricity consumption will reach to } 500 \text { TWh by } 2020 \\
\text { where industrial, residential, agricultural and transport sector } \\
\text { electricity consumption are forecasted } \\
\text { 219TWh } 257 \text { TWh } 20 \text { TWh } 4 \text { TWh respectively. }\end{array}$ \\
\hline Erdogdu (2007) & $\begin{array}{l}\text { Electricity } \\
\text { Consumption per } \\
\text { capita }\end{array}$ & $\begin{array}{l}\text { Partial Adjustment } \\
\text { Model \& ARIMA }\end{array}$ & $\begin{array}{l}\text { Long term and short Term price elacticities are }-0.04 \text { and }-0.030 \\
\text { respectively, income elasticity is } 0.06 \text { in short term and } 0.41 \text { in } \\
\text { the long term. Electricity consumption is projected to reach to } 160 \\
\text { TWh by } 2014\end{array}$ \\
\hline $\begin{array}{l}\text { Halicioglu } \\
\text { (2007) }\end{array}$ & $\begin{array}{l}\text { Residential } \\
\text { Electricity } \\
\text { Consumption per } \\
\text { capita }\end{array}$ & $\begin{array}{l}\text { Bounds testing } \\
\text { Cointegration } \\
\text { Approach }\end{array}$ & $\begin{array}{l}\text { Long term and short term price elasticities are varying }-0.52 \text { to - } \\
0.63 \text { and }-0.33 \text { to }-0.46 \text { respectively and where long term and short } \\
\text { term income elasticities varying } 0.49 \text { to } 0.70 \text { and } 0.37 \text { to } 0.44 \\
\text { correspondingly according to lag criteria. Urbanization rate is a } \\
\text { significant factor and has a } 0.04 \text { and } 0.90 \text { effects in the long term } \\
\text { and in the short term respectively. }\end{array}$ \\
\hline $\begin{array}{l}\text { Ediger and Akar } \\
\text { (2007) }\end{array}$ & $\begin{array}{l}\text { Primary Energy } \\
\text { Consumption }\end{array}$ & ARIMA & $\begin{array}{l}\text { In the low case scenario the total primary energy consumption is } \\
\text { projected to be } 135.896 \text { mtoe and in the high case scenario it will } \\
\text { reach to } 152.285 \text { mtoe by } 2020\end{array}$ \\
\hline $\begin{array}{l}\text { Jobert and } \\
\text { Karanfil (2007) }\end{array}$ & $\begin{array}{l}\text { Sectoral Energy } \\
\text { Consumption by } \\
\text { Source and Growth }\end{array}$ & $\begin{array}{l}\text { Granger Causality- } \\
\text { Instantaneous } \\
\text { Causality }\end{array}$ & $\begin{array}{l}\text { There is no evidence of a long term relationship between energy } \\
\text { and income. They appear to be neutral with respect to each other. } \\
\text { Strong evidence is found for instantaneous causality between } \\
\text { variables. }\end{array}$ \\
\hline $\begin{array}{l}\text { Lise and } \\
\text { Montfront } \\
\text { (2007) }\end{array}$ & $\begin{array}{l}\text { Electricity } \\
\text { Consumption and } \\
\text { Economic Growth }\end{array}$ & Granger Causality & The causality is running from GDP to Energy consumption \\
\hline $\begin{array}{l}\text { Akay and Atak } \\
\text { (2006) }\end{array}$ & $\begin{array}{l}\text { Total and } \\
\text { Industrial } \\
\text { Electricity } \\
\text { Consumption }\end{array}$ & $\begin{array}{l}\text { Grey Prediction } \\
\text { with Rolling } \\
\text { Mechanism }\end{array}$ & $\begin{array}{l}\text { It is projected that industrial and total consumption will be } 140.37 \\
\text { and } 265.7 \mathrm{TWh} \text { in } 2015 \text {, respectively. }\end{array}$ \\
\hline
\end{tabular}


Table 1: Continued

\begin{tabular}{|c|c|c|c|}
\hline $\begin{array}{l}\text { Altinay and } \\
\text { Karagol (2005) }\end{array}$ & $\begin{array}{l}\text { GDP and Energy } \\
\text { Consumption }\end{array}$ & $\begin{array}{l}\text { VAR and Granger } \\
\text { Causality }\end{array}$ & $\begin{array}{l}\text { Unidirectional causality running from electricity } \\
\text { consumption to income }\end{array}$ \\
\hline $\begin{array}{l}\text { Ozturtk and } \\
\text { Ceylan (2005) }\end{array}$ & $\begin{array}{l}\text { Total Energy } \\
\text { Consumption }\end{array}$ & $\begin{array}{l}\text { Genetic Algorithm } \\
\text { Approach }\end{array}$ & $\begin{array}{l}\text { Genetic algorithm approach might be a better estimation } \\
\text { method when it is compared with MAED projections of } \\
\text { MENR. }\end{array}$ \\
\hline $\begin{array}{l}\text { Ozturk et al. } \\
\text { (2003) }\end{array}$ & $\begin{array}{l}\text { Total Electricity } \\
\text { Consumption }\end{array}$ & $\begin{array}{l}\text { Genetic Algorithm } \\
\text { Approach }\end{array}$ & $\begin{array}{l}\text { Genetic algorithm approach might be a better estimation } \\
\text { method when it is compared with MAED projections of } \\
\text { MENR. }\end{array}$ \\
\hline $\begin{array}{l}\text { Ediger and } \\
\text { Tatlidil (2002) }\end{array}$ & $\begin{array}{l}\text { Primary Energy } \\
\text { Demand }\end{array}$ & Univariate cycle analysis & The primary energy demand will reach 130 mtoe by 2010 \\
\hline $\begin{array}{l}\text { Bakirtas et al. } \\
\quad \text { (2000) }\end{array}$ & $\begin{array}{l}\text { Total Electricity } \\
\text { Consumption per } \\
\quad \text { capita }\end{array}$ & $\begin{array}{l}\text { Engle-Granger two step } \\
\text { procedure \& ARMA }\end{array}$ & $\begin{array}{l}\text { Insignificant price elasticity income elasticity, } 0.7 \text { short run } \\
\text { and } 3.1 \text { long run. }\end{array}$ \\
\hline
\end{tabular}

On the other hand, Hamzacebi (2007) using Artificial Neural Networks and Akay and Atak (2006) using the Grey Prediction with Rolling Mechanism, focused on forecasting Turkish industrial electricity demand. Hamzacebi (2007) concluded that in 2020 industrial electricity demand would reach just less than 220 TWh while Akay and Atak (2006) argued that in 2015 it would be about $140 \mathrm{TWh}$. However, both of these studies could arguably be criticised for their failure to take account of the electricity price and economic activity in driving future electricity demand - which might result in forecasts being somewhat different from outturn.

Another aspect that has not been investigated in previous studies of Turkish industrial energy consumption is the impact of technical progress and the energy efficiency of the industrial; sector's capital stock (or the wider concept of the UEDT). This is discussed in more detail in the next section. 


\subsection{Review of technical progress and Underlying Energy Demand Trend (UEDT)}

Technological progress of the capital stock is an important factor that influences industrial energy demand. Energy is a derived demand rather than being demanded for its own sake; it is the demand for the services it produces with the capital stock in place at a certain time. The amount of energy consumed is therefore connected to the technology level of the energy appliances to assure the demanded level of services. Beenstock and Willcocks (1981) therefore argued that technological progress should be taken into account in energy modelling studies and used a simple deterministic trend in their study. However, Kouris (1983a, 1983b) criticized this, arguing that although technology is an important determinant of energy demand, there is no sufficient way to identify its effect on energy demand unless a sufficient way to measure it can be addressed. Moreover, in the absence of the appropriate measure, Kouris argued that the effect of technological progress could therefore be observed via the response to energy price changes, the price elasticity. In response, Beenstock and Willcocks (1983) argued that it is important to attempt to capture the exogenous effect of technological progress and, although using a linear trend is not an adequate way, it is better than just ignoring it.

Hunt et al. (2003a and 2003b) agreed that technical progress should be captured in energy demand models arguing that it is important to distinguish between the exogenous impact and the endogenous price (and income) effects. Furthermore, Hunt et al. (2003a and 2003b) argued that in addition to technical change and the change in energy efficiency of the capital stock there are a number of additional exogenous factors that will also affect the demand for energy. These include changes in such factors as consumer tastes and preferences, demographic and social structure, environmental regulations, economic structure, etc. Hunt et al. (2000, 2003a and 2003b) therefore introduced the wider concept of the Underlying 
Energy Demand Trend (UEDT) that encompasses technical change of the capital stock and the other exogenous factors. ${ }^{1}$ However, Hunt et al. (2003a and 2003b) argued that given the way technical progress is introduced and the likely 'lumpiness' of other exogenous factors, it is unlikely that the UEDT would be linear - as given by incorporating a deterministic time trend in an estimated energy demand function. Instead, they argue that the UEDT is likely to be non-linear and could incorporate periods where it is downward sloping (energy saving) and periods where it might be upward sloping (energy using). Thus, according to Hunt et al. (2003a and 2003b) it is important to model the UEDT in the most general and flexible way possible, and therefore recommended the use of the STSM introduced by Harvey et al. (1986), Harvey (1989), Harvey and Shephard (1993), Harvey and Scott (1994) and Harvey (1997). The STSM and its application to energy demand models are therefore discussed further in the next section.

\subsection{Structural Time Series Models and application to energy demand studies}

\subsubsection{The Structural Time Series Model (STSM)}

The structural approach consists of decomposing the dependent variable (energy consumption) into the impact of the explanatory variables (such as price and income/output) plus trend and irregular components. Although it is possible to establish a model based on a deterministic trend, the preferred flexibility can be achieved by letting the trend change over time and therefore be stochastic. A basic univariate STSM can be explained as a regression in which the parameters are changing over time and explanatory variables are functions of time.

\footnotetext{
${ }^{1}$ Hunt et al. (2003a) also argued that if the UEDT is not included (or incorrectly modelled) then this could lead to biases in the estimated price and income elasticities; for example, if the true UEDT is downward sloping then the income elasticity will be underestimated by not taking account of the UEDT.
} 
State space form of a STSM is a presentation of the state of a system with unobserved components including a trend. By introducing new observations to the system, the estimate of unobservable components can be updated by means of a filtering procedure. Predictions are made, based on carrying these estimated parameters into the future while smoothing the algorithm in order to obtain the best estimate of the state at any point (Harvey and Shephard, 1993; Commandeur and Koopman, 2007; Durbin and Koopman, 2001; Harvey et al., 2005; and Harvey and Proietti, 2005). Further explanation of the STSM will be given in the methodology section.

\subsubsection{The STSM in energy demand studies}

The STSM is a relatively new method; hence, there are few applications to energy demand. Harvey and Koopman (1993) within the context of STSM and by using time varying splines examined hourly electricity demand for northwest US. Hunt et al. (2000) was the first attempt to use the STSM to estimate a UEDT for UK final consumption of coal, gas, oil, petroleum, electricity, and total energy by using quarterly data over period 1972 to 1995. They concluded that the UEDT has a stochastic, rather than deterministic, form as previously used in conventional models. Furthermore, the estimated UEDT was found to be fluctuating over time, illustrating that energy demand is affected by exogenous unobserved influences. Hunt et al. (2003a and 2003b) investigated UK aggregate energy demand using the STSM for various sectors of the UK using quarterly data over period 1972 to 1997 and concluded that stochastic trends and seasonals are better when modelling energy demand. Similarly, Dimitropoulos et al. (2005) demonstrated again that the STSM approach is superior by implementing the stochastic rather than deterministic trend when investigating sectoral aggregate energy demand using annual UK data over period 1967 to 2002. Hunt and Ninomiya (2003) investigated transportation oil demand for the UK and Japan by using the 
STSM with quarterly data over the period 1971 and 1997, test their results against conventional deterministic trends, and argue that the stochastic trend from the STSM is more appropriate than a deterministic one. Amarawickma and Hunt (2008) estimated Sri Lankan electricity demand functions by using six different methods including the STSM approach and showed that the technique performed equally as well compared to cointegration econometric approaches; but implicitly showed that the STSM was the only technique that allowed an exogenous non-linear trend to be identified. Doornat et al. (2008) investigated French hourly electricity load by employing a multivariate periodic state space model that included a stochastic trend and concluded that their model gives satisfactory prediction results for one, two and three day ahead but some improvements can be made for longer prediction periods.

Therefore, given the discussion above, the STSM is the adopted methodology here for estimating Turkish industrial energy demand. Although cointegration is used by the majority of energy demand studies using time series data, the cointegration methodology is seen as too inflexible for the complexities of modelling industrial energy demand since it is not possible to estimate a non-linear UEDT. Moreover, Harvey (1997) strongly advocates the use of the STSM, and criticises unit root tests and the cointegration methodology as unnecessary and/or a misleading procedure due to, amongst other things, its poor statistical properties. The STSM methodology used in this study is therefore outlined in the next section. 


\section{Methodology:}

It is assumed that Turkey's industrial electricity demand is identified by:

$E_{t}=f\left(Y_{t}, P_{t}, U E D T_{t}\right)$

Where: $E_{t}=$ industrial electricity demand;

$Y_{t}=$ industrial value added (or 'output' for short);

$P_{t}=$ real industrial electricity price; and

$U E D T_{t}=$ Underlying Energy Demand Trend for industrial electricity.

For the econometric estimation of equation (1) the dynamic autoregressive distributed lag specification is utilised as follows:

$A(L) e_{t}=B(L) y_{t}+C(L) p_{t}+U E D T_{t}+\epsilon_{t}$

where $A(L)$ is the polynomial lag operator $1-\lambda_{1} L-\lambda_{2} L^{2}-\lambda_{3} L^{3}-\lambda_{4} L^{4} ; B(L)$ is the polynomial lag operator $1+\varphi_{1} L+\varphi_{2} L^{2}+\varphi_{3} L^{3}+\varphi_{4} L^{4} ; C(L)$ is the polynomial lag operator $1+\varphi_{1} L+$ $\varphi_{2} L^{2}+\varphi_{3} L^{3}+\varphi_{4} L^{4}$ and

$$
\begin{aligned}
& e_{t}=\operatorname{Ln}\left(E_{t}\right) ; \\
& y_{t}=\operatorname{Ln}\left(Y_{t}\right) ; \\
& p_{t}=\operatorname{Ln}\left(P_{t}\right) ;
\end{aligned}
$$

$B(L) / A(L)=$ the long run output elasticity of industrial electricity demand;

$C(L) / A(L)=$ the long run price elasticity of industrial electricity demand; and $\varepsilon_{t}=$ a random error term. $^{2}$

The UEDT is stochastic and can be estimated by the STSM, consisting of level and slope components with the following formulation:

$\mu_{t}=\mu_{t-1}+\beta_{t-1}+\eta_{t} ; \quad \eta_{t} \sim N I D\left(0, \sigma_{\eta}^{2}\right)$

\footnotetext{
${ }^{2}$ A four-year lag is chosen for the polynomial lag operator s since it is seen as a reasonable length to capture any possible dynamics.
} 
$\beta_{t}=\beta_{t-1}+\xi_{t} ; \quad \xi_{t} \sim N I D\left(0, \sigma_{\xi}^{2}\right)$

Where;

$\mu_{t}=$ Level of the UEDT

$\beta_{t}=$ Slope of the UEDT

$\eta_{t}$ and $\xi_{t}$ are the mutually uncorrelated white noise disturbances with zero means and variances $\sigma_{\eta}^{2}$ and $\sigma_{\xi}^{2}$ respectively. Larger variances cause greater stochastic movements in the trend; $\eta_{t}$ allows the level of trend to shift up and down and $\xi_{t}$ allows the slope to change (Harvey and Shephard, 1993). The shape of the underlying electricity demand trend is determined by these hyper-parameters including $\sigma_{\xi}^{2}, \sigma_{\eta}^{2}$ and $\sigma_{\varepsilon}^{2}$. The hyper-parameters and other parameters of the model are estimated by a combination of maximum likelihood and the Kalman filter. Equation residuals and a set of auxiliary residuals are also estimated in order to evaluate the model. The auxiliary residuals consist of smoothed estimates of model disturbances (the 'irregular residuals'), smoothed estimates of the level disturbances (the 'level residuals'), smoothed estimates of the slope disturbances (the 'slope residuals').

In order to maintain the normality of the auxiliary residuals, some irregular, slope and level interventions can be identified (Koopman et al. 2000). These interventions generally give information about important breaks and structural changes at certain dates during the estimation period. The irregular intervention can be described as a pulse effect since it has only a temporary effect on the UEDT; it is therefore a short run response normally used to account for an unexpected event or shock. However level and slope interventions do have a permanent effect on the estimated UEDT; hence, these effects are longer lasting. In energy demand modelling, these interventions normally illustrate a 'structural change' that might arise because of a number of factors that are captured by the estimated UEDT, as discussed 
above. If there are no interventions then the estimated UEDT is given by $\mu_{t}$ however when there are interventions it is given by:

$\mathrm{UEDT}=\mu_{t}+$ irregular interventions + level interventions + slope interventions

Therefore, in addition to identifying appropriate interventions, the estimation strategy involves estimating Equations (2), (3), (4) and (5) and testing down by excluding statistically insignificant variables, providing the model passes an array of diagnostic tests (see results section for details). The software package STAMP 8.10 (Koopman et al., 2007) is used to estimate the model and the results given in the next section after discussing the data.

\section{Data and estimation results}

\subsection{Data}

Annual time series data from 1960-2008 for E (industrial electricity consumption KWh), Y (Industrial Value Added in 2005 constant Yeni Turk Lirasi, YTL) and P (real industrial electricity prices in 2005 constant YTL) are used for the analysis. E is obtained from the International Energy Agency (IEA, 2010), Y from the World Bank (World Bank, 2010) and nominal industrial electricity prices are obtained from the archives of the SIS, the MENR, and IEA (2010). In order to obtain the real industrial energy price, $\mathrm{P}$, the nominal prices are deflated by Turkey's Consumer Price Index obtained from the World Bank (World Bank, 2010). 


\subsection{Results}

After eliminating the insignificant variables and including interventions, (irregular for 1991, level for 1979 and slope for 1981), in order to maintain the normality of residuals and auxiliary residuals, the preferred estimated equation is given by:

$e_{t}=0.14969 y_{t}-0.16086 p_{t}+U E D T_{t}$

Where the estimated UEDT is 20.8124 at the end of the estimation period with a slope of $0.04793 .^{3}$ The detailed estimation results and the diagnostics tests are given in Table 2 and Figure 2.

The preferred model passes all the diagnostic tests including the additional normality tests for the auxiliary residuals generated by the STSM approach, with no need for any dynamic terms giving estimated short and long run industrial output and price elasticities of 0.15 and -0.16 respectively. Therefore, the estimated price elasticity is between previous Turkish estimates discussed above, being greater (in absolute terms) than that found by Bakirtas et al. (2000) but less than that found by Erdogdu (2007) and Halicioglu (2007). However, the estimated income elasticity is somewhat lower than that found by Bakirtas et al. (2000), Erdogdu (2007), and Halicioglu (2007). Nevertheless, these previous Turkish studies were not for the industrial sector and importantly, did not allow for a UEDT; hence, it is not surprising that they found a bigger income effect.

\footnotetext{
${ }^{3}$ The figure of 0.04793 (representing an annual increase of just under 5\%) is the sum of the estimated slope at the end of the period of 0.086766 and the estimated coefficient for the slope intervention of -0.0338 (Figure 4).
} 
Table 2: Turkish Industrial Electricity Demand STSM Estimates and Diagnostics Sample 1960-2008

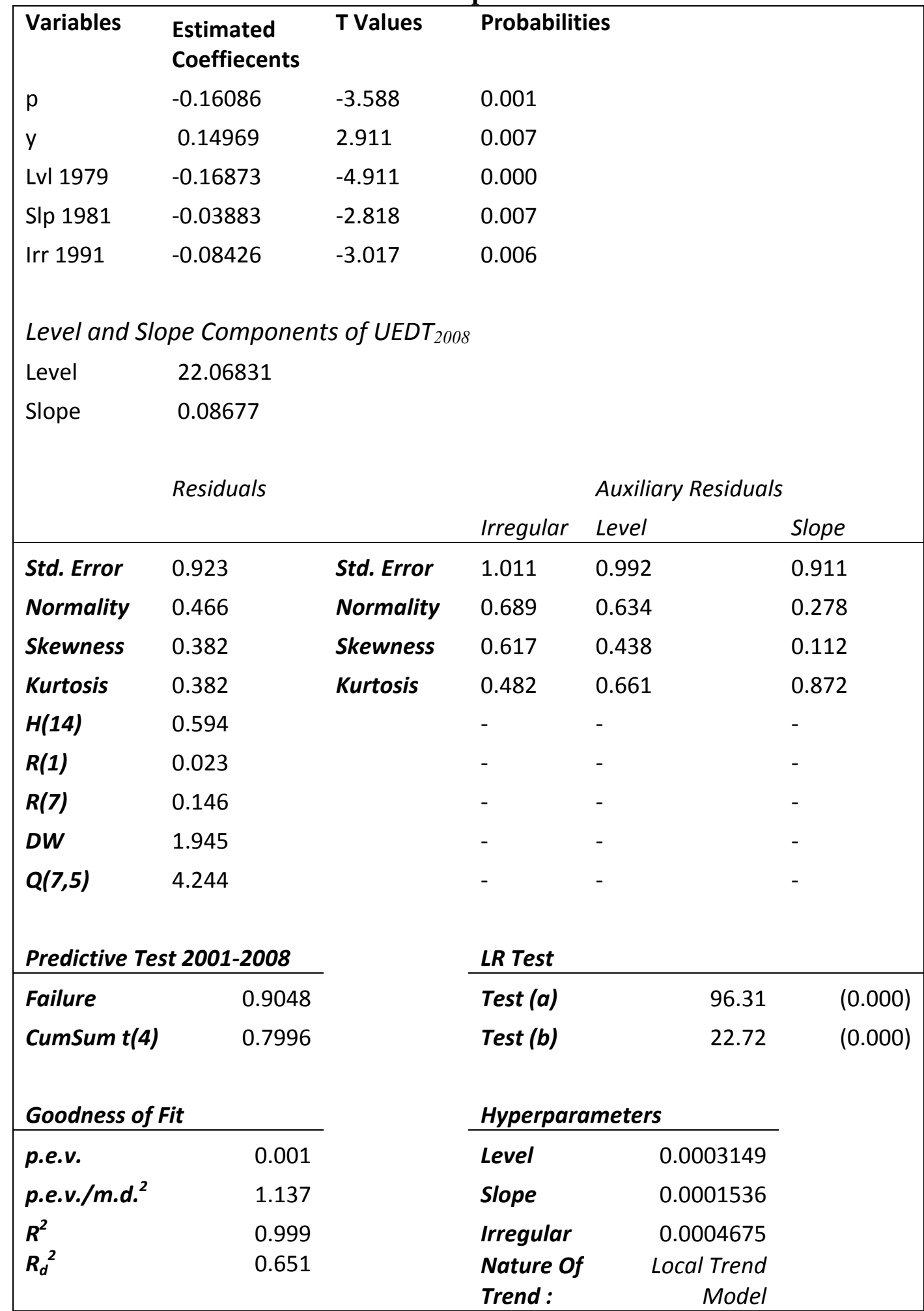

Notes:

-Model estimation and all statistics are from STAMP 8.10;

-Model includes a level intervention for the year 1979, a slope intervention for the year 1981 and an irregular for the year 1991; 
Notes for table 2 Continued:

-Prediction Error Variance (p.e.v.), Prediction Error Mean Deviation (p.e.v./m.d.2) and the Coefficients of Determination $\left(R^{2}\right.$ and $R d^{2}$ ) are all measures of goodness-of-fit;

-Normality (corrected Bowman - Shenton), Kurtosis and Skewness are error normality statistics, all approximately distributed as $\chi 2$ (2); as $\chi 2$ (1); as $\chi 2$ (1) respectively;

$-H(14)$ is a Heteroscedasticity statistic distributed as $F(14,14)$;

$-r(1)$ and $r(7)$ are the serial correlation coefficients at the equivalent residual lags, approximately normally distributed;

-DW is the Durbin-Watson statistic;

$-Q(7,5)$ is the Box - Ljung statistic distributed as $\chi^{2(5)}$;

-Failure is a predictive failure statistic distributed as $\chi 2(8)$ and Cusum is a mean stability statistic distributed as the Student t distribution; both are STAMP prediction tests found by re-estimating the preferred model up to 2000 and predicting for 2001 thru 2008;

-LR Test(a) represent likelihood ratio tests on the same specification after imposing a fixed level and zero slope hyperparameter and Test(b) after imposing a fixed level and fixed slope; both are distributed as $\chi^{2(2)}$ and probabilities are given in parenthesis.

Figure 2: STAMP Predictive Tests Graphics

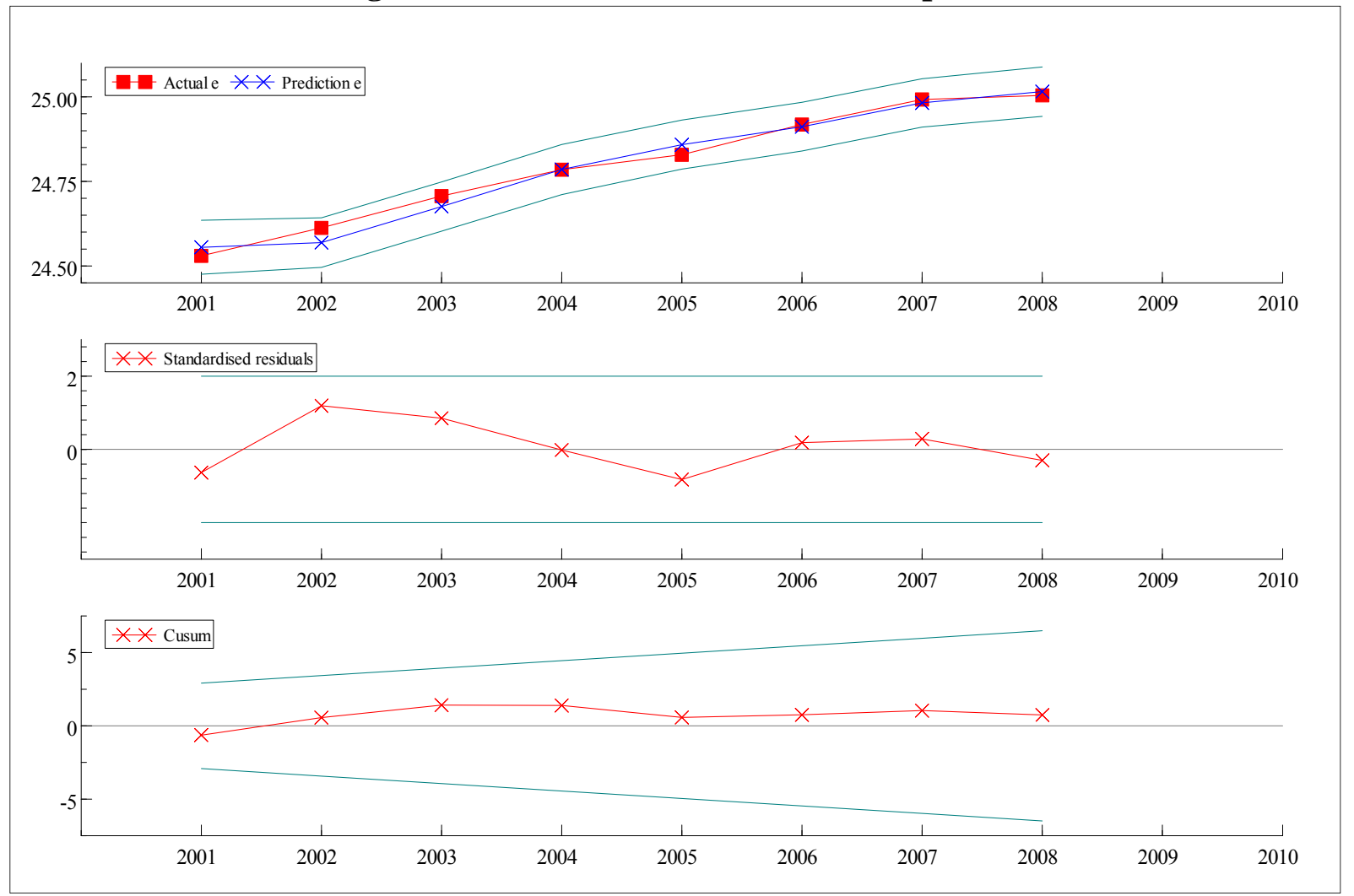


As discussed above, the irregular, the slope and level residuals need to be normally distributed, and during the estimation process, it was found that some interventions were needed to ensure this condition is maintained. As also discussed above, from a statistical standpoint, the existence of such interventions in the STSM might be a sign of a structural break and instability over the estimation period; however, from an economics standpoint, the interventions provide valuable information about certain events and periods that affects electricity consumption behaviour and therefore warrants further investigation. In this case, the preferred estimated equation for Turkish industrial electricity demand required interventions in 1979, 1981 and 1991 (as level, slope, and irregular interventions correspondingly) all of which can be identified as important events:

- the level intervention for 1979 probably reflects the serious economic crises that Turkey experienced resulting from the oil price hike. This caused a large decrease in GDP and led to a military coup, and therefore the estimated output elasticity for industrial energy demand would be unlikely to adequately pick up this shift effect;

- the slope intervention for 1981 probably reflects the important change in Turkish industrial electricity consumption, because of the first implementation of planned energy conservation activities for the industrial sector by the General Directorate of Electrical Power Resources Survey Administration-EIE (Hepbasli and Ozalp 2003); and

- the irregular intervention for 1991 probably reflects the economic crisis that year following from the Gulf war and sanctions against Iraq; the export oriented Turkish industrial sector was quite negatively affected bringing about a $4 \%$ reduction in 
industrial electricity consumption, which would not be captured adequately by the estimated output and price elasticities (being outside the usual 'norm').

It would appear that the 1991 and 1979 crises effected Turkish industry in a different manner. As discussed in the introduction, prior to the 1980s the Turkish economy was inward looking with an import-substituting industrialization strategy; whereas, after 1980 the strategy changed with an export oriented industrialization strategy adopted. Therefore, before 1980 the domestic market is more important whereas after 1980 exports became more important. Even though Turkey experienced a bigger domestic economic crisis in 2001 compared to 1991, the 1991 crises had a narrowing effect on export potential of Turkey because of the first gulf war

The estimated UEDT from this procedure is non-linear given the estimated hyper-parameters (Table 2) and is illustrated in Figure 3. It can be seen that the estimated stochastic trend is generally increasing (but at a decreasing rate) over the estimation period, i.e. it is generally energy using. It also clear in Figure 4, given the interventions, that there is a level drop in 1979 and the slope changes at 1981; moreover Figure 4 illustrates that the slope and the 'adjusted slope' generally diminishes over the estimation period. ${ }^{4}$ The preferred equation and the estimated non-linear UEDT are now used to construct future scenarios for Turkish energy demand, which are explained in the next section.

\footnotetext{
${ }^{4}$ The estimated 'adjusted slope' is equal to the estimated slope plus the slope intervention.
} 
Figure 3: Underlying Electricity Demand Trend (UEDT) of Turkish Industrial Sector Electricity Consumption 1960-2008

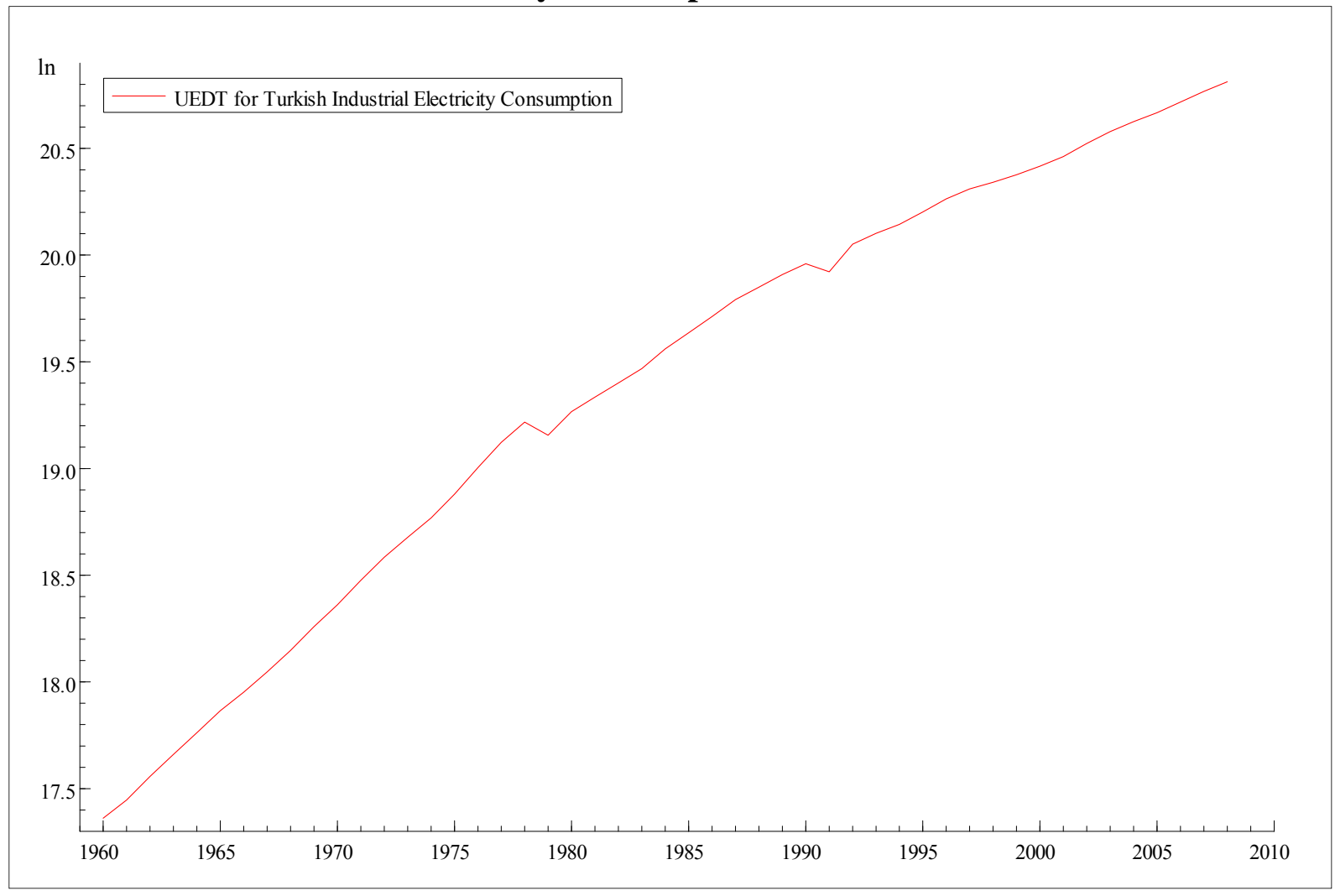

Figure 4: Slope and Level of UEDT for Turkish Industrial Sector 1960-2008

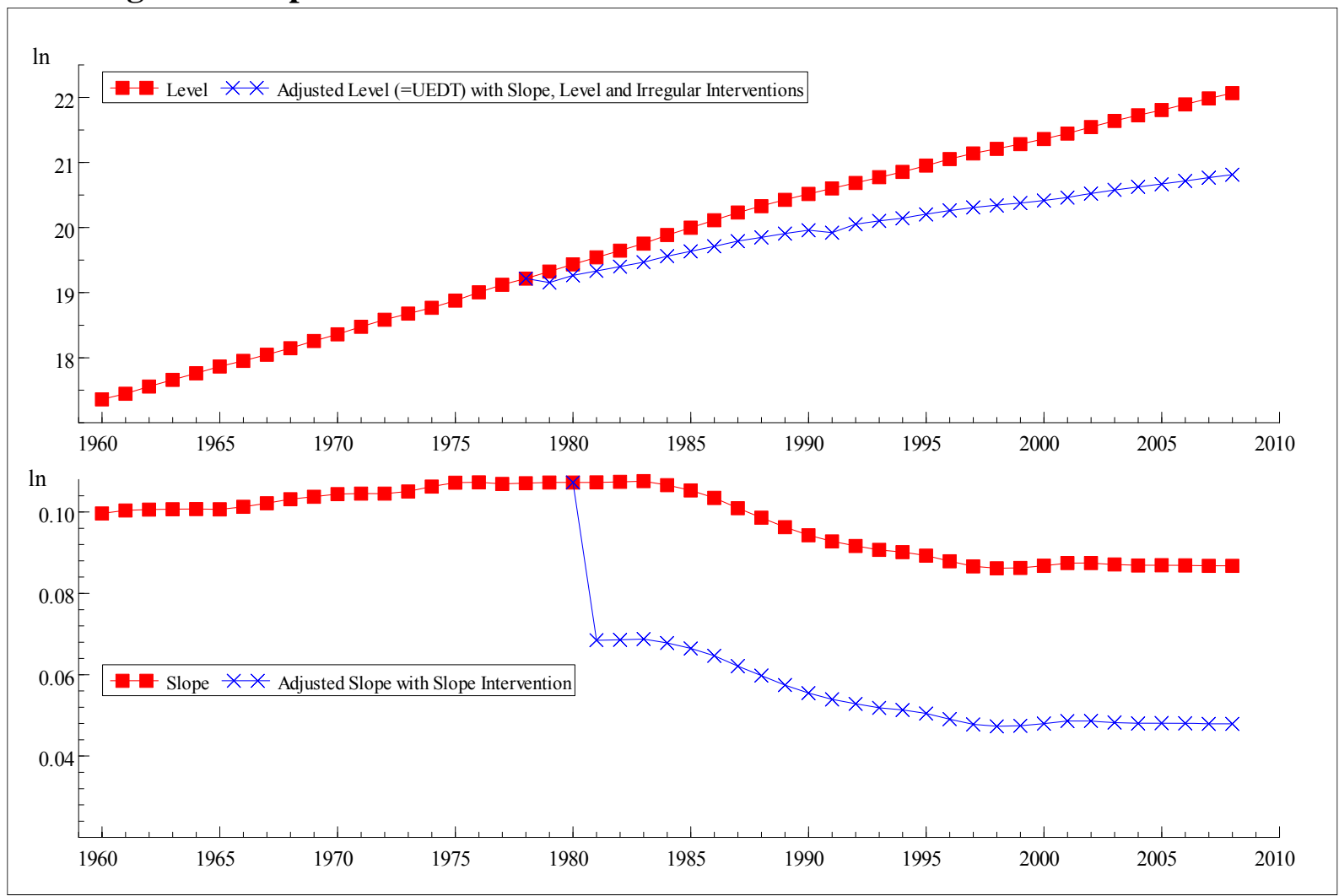




\section{Forecasting Assumptions and Results:}

In this section, the forecast assumptions and the forecast results based on these assumptions will be illustrated.

\subsection{Forecast Assumptions:}

Three scenarios are implemented with different assumptions namely 'low', 'reference' and 'high' case. In the 'low' case and the 'high' case scenarios, combinations of economic variables are chosen that 'minimize' and 'maximize' the electricity demand respectively. Although, where data (and 'intelligence') are available for 2009 (such as the nominal industrial electricity price $)^{5}$ these are used in all scenarios. In the 'reference' scenario, what is seen as the 'most probable' outcome for these economic variables is assumed. While the adjusted slope of the UEDT is assumed to declining at the same rate as the estimated adjusted slope over the estimation period. For the 'low' and 'high' cases, an appropriate variation for both the variables and the UEDT is assumed - as discussed below.

The detailed information about these scenarios is as follows.

- In the 'reference' scenario, it is assumed that real industrial electricity prices will increase 1\% after 2009 annually. The Turkish Parliament ratified the Kyoto protocol and it is likely that the government will introduce measures such as carbon taxes and incentives to encourage renewables, which are likely to contribute to an increase in end use prices of electricity. However, the improving efficiency in electricity generation is likely to reduce the cost and hence, counteract the price increase to some

\footnotetext{
${ }^{5}$ In 2009, Turkish industrial electricity prices increased by $18 \%$ in nominal terms. At the time of writing, the required deflator (the Consumer Price Index from World Bank) is not available, although it is known that Turkish inflation was around $6.5 \%$ in 2009 ; hence based on this the real industrial electricity price is assumed to have increased by $11.5 \%$ in 2009 for all three scenarios.
} 
extent. Consequently, it is assumed that real electricity prices will increase $1 \%$ annually. The increase of industrial value added is expected to be $1.5 \%$ in 2009 , and 2\% in 2010 and 2011 because of the global crises. It is further assumed that there would then follow a recovery period with annual increases of $2.5 \%, 3 \%$ and $3.5 \%$ for 2012 to 2015 and a 4\% per annum thereafter. Given that the adjusted slope of the UEDT generally diminishes over the estimation period, it is assumed that this will continue into the future, hence it is assumed that the adjusted slope decreases by 0.0011 each year from the estimated value of 0.04793 in the last period of the estimation. ${ }^{6}$ It implicitly assumes that the annual change in exogenous 'energy using' behaviour for Turkish industrial electricity demand at the end of the estimation period will continue to increase but at a decreasing rate throughout the forecast period.

- In the 'low' case scenario, it is assumed that the reduction in the costs of power production due to increased efficiency in electricity generation are relatively small; hence these savings are outweighed by the rise in prices brought about from the measures introduced in order to comply with the Kyoto Protocol. The assumed rise in real electricity prices is therefore $2 \%$ per annum after 2009 . For industrial value added it is assumed that it will decrease 3\% in 2009 and increase $0.5 \%$ in 2010 and 2011 because of the global economic crises and increase by $1 \%$ in $2012,1.5 \%$ in 2013, 1.5\% in 2014, 2\% per year in 2015 and 2016 and 2.5\% thereafter until 2020. Because of improved efficiency and faster transformation of the Turkish industrial sector, it is assumed that the adjusted slope of the UEDT decreases by 0.0033 each

\footnotetext{
${ }^{6}$ The figure of -0.0011 being the average change in the estimated adjusted slope over the estimation period.
} 
year. ${ }^{7}$ It is thus assumed that the exogenous underlying 'energy using' behaviour for Turkish industrial electricity demand will continue throughout the forecast period, but is offset by some improvement in efficiency. Furthermore, for the UEDT a shock effect is included for 2009 with the same magnitude as that estimated by the irregular intervention for 1991 in order to take into account a shock that might have occurred because of the global crisis.

- In the 'high' case scenario, the real industrial electricity price is assumed to increase $0.5 \%$ per year over the period 2010 to 2020 period. Even though the Kyoto protocol is ratified by the Turkish parliament, and is likely to result in new carbon taxes, in this scenario it is assumed that the increasing efficiency standards in electricity generation will decrease the cost of power production. Therefore, it is assumed that these two factors balance each other out and the electricity price will increase only $0.5 \%$ per year in real terms. Furthermore, it is assumed that industrial value added will increase by $3 \%$ each year in 2009 and 2010 and $2.5 \%$ in 2011, because of the global economic crisis. It is further assumed that this is followed by a recovery period with an increase of $3 \%$ in $2012,3.5 \%$ per year in $20134.5 \%$ per year in 2014 and $2015,5 \%$ per year in 2016 and 2017 and slightly higher at 6\% per year thereafter. For the UEDT, it is assumed that the slope will increase by 0.0011 each year; ${ }^{8}$ implicitly assuming that the exogenous 'energy using' behaviour for Turkish industrial electricity demand increases at an even greater pace.

\footnotetext{
${ }^{7}$ The figure of -0.0033 is obtained by assuming that over the forecast period the adjusted slope declines by an additional factor of two of the average change over the estimation period.

${ }^{8}$ The figure of +0.0011 mirrors that assumed for the 'low' scenario.
} 
Figure 5a: High, Reference and Low Case Scenarios for Real Industrial Value Added and Real Industrial Electricity Prices 1985-2020

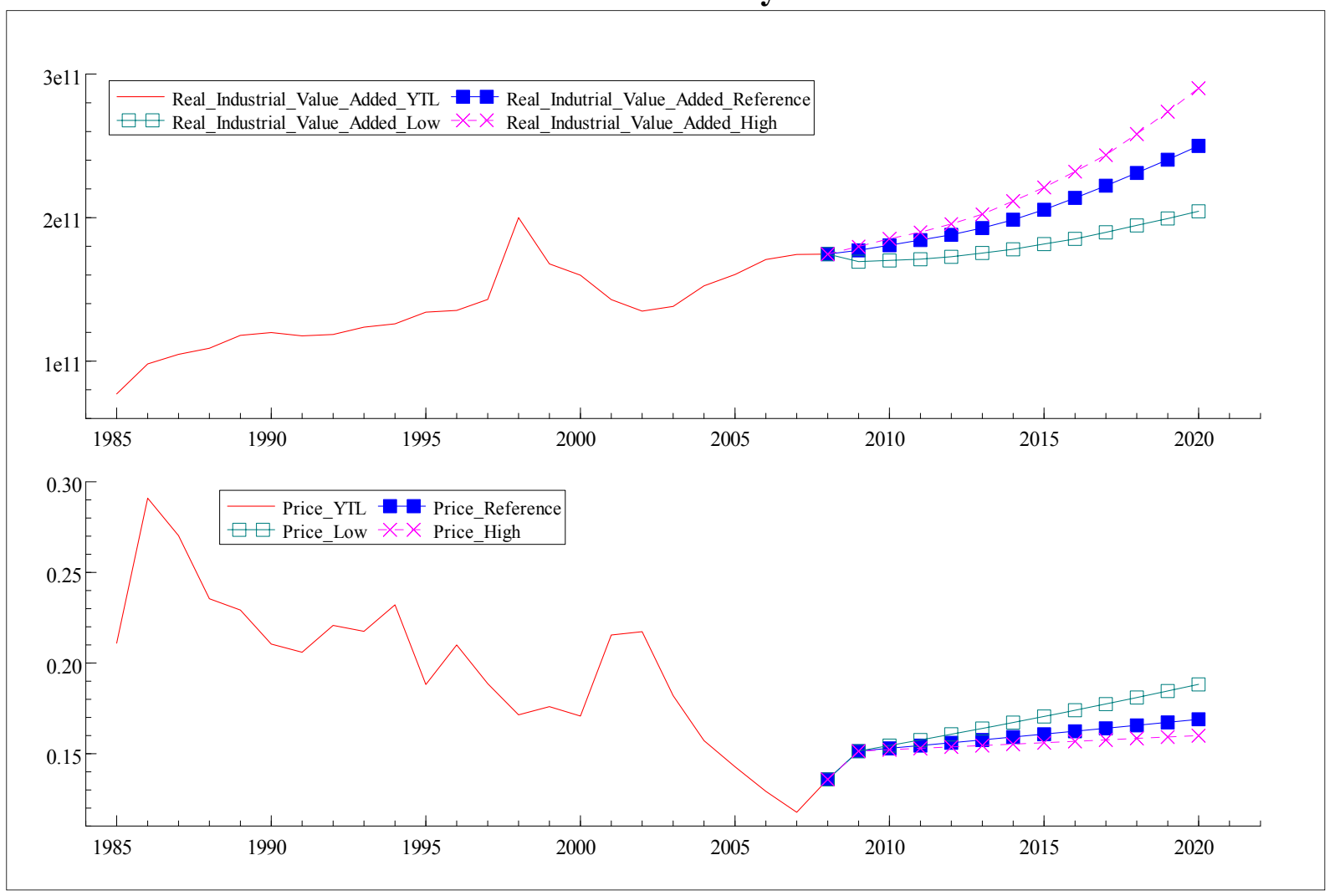

Figure 5b: High, Reference and Low Case Scenarios for UEDT and Adjusted Slope of UEDT 1985-2020

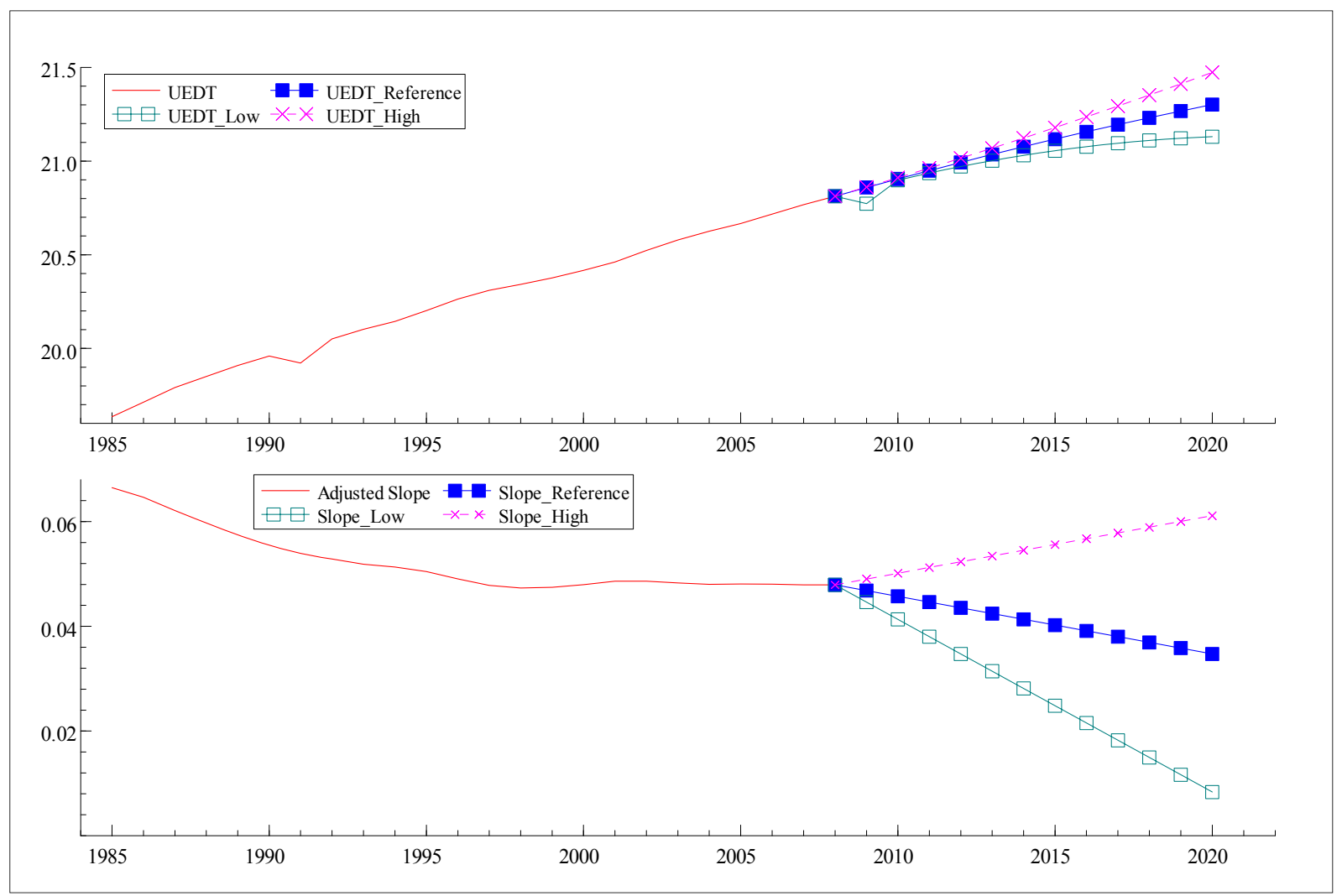


Figure 5a, illustrates the assumptions for all three scenarios for value added and real industrial electricity prices; and the bottom half of Figure 5b illustrates the different forecast trajectories for the adjusted slope of the UEDT and the resultant impact on the UEDT is illustrated in the top half of Figure $5 b$.

\subsection{Forecast Results:}

Based on the estimated equation presented in the previous section and applying the scenario assumptions discussed above, Turkish industrial is predicted to be 97, 121 and $148 \mathrm{TWh}$ by 2020 according to the 'low', 'reference' and 'high' case scenarios respectively. The paths to 2020 for the three scenarios are illustrated in Figure 6.

Figure 6: Turkey's Industrial Electricity Demand Forecast over the period 2009-2020

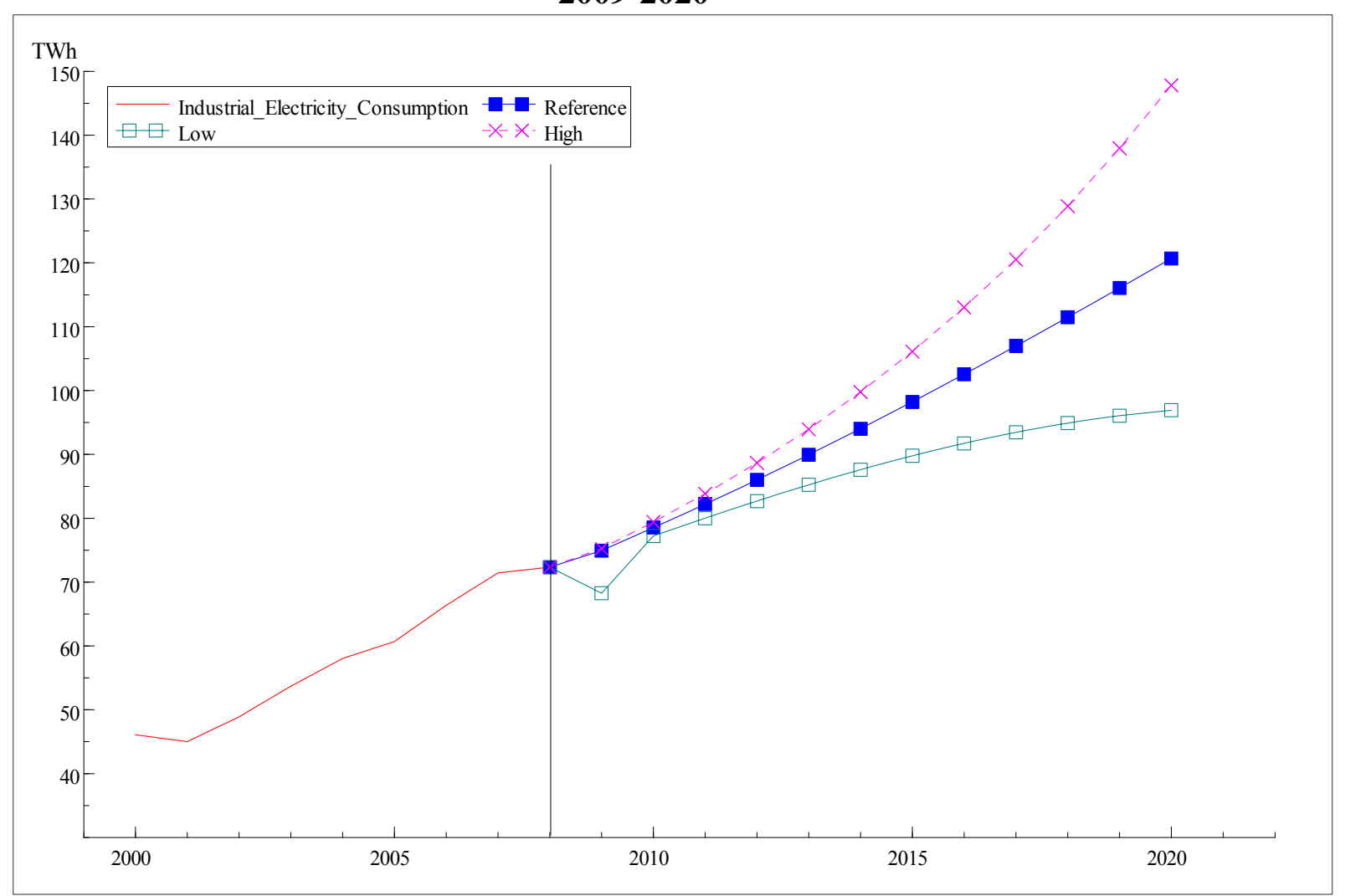




\section{Conclusion and Topics for Further Discussion:}

The previous energy forecasts for Turkey tended to over-predict, with the forecasts being generally greater than outturn. It has been argued that one reason for this was the previous methods employed and that a methodology that incorporates a stochastic UEDT, structural changes and breaks in energy consumption behaviour and the impact of previous shocks in addition to explicitly modelling price and output effects should produce more reliable forecasts. Given this argument, the STSM was employed here to model Turkish industrial energy demand, providing an appropriate model for producing forecast scenarios for Turkish industrial energy demand. A requirement if previous under utilisation of power generating capacity is to be avoided in the future.

The estimated industrial value added (output) elasticity is 0.15 and the estimated industrial energy price elasticity is -0.16 . Furthermore, the UEDT for the Turkish industrial sector is uncovered, showing that, ceteris paribus, although electricity demand has been increasing, the underlying rate of increase appears to be diminishing with a significant structural change in 1981. This might well reflect the implementation of the first planned energy conservation activities by the General Directorate of Electrical Power Resources Survey AdministrationEIE (Hepbasli and Ozalp 2003), and illustrates the power of structural time series modelling in identifying structural changes.

Because of the recent global economic crisis and the export-oriented nature of the Turkish industrial sector a similar impact to that observed in 1991 might be observed again. Although the Turkish economy has experienced several economic crises, it is expected that the effect of the current global economic crisis might have an important impact on future industrial electricity demand at least in the short to medium term; hence, it is incorporated in the 'low' 
industrial electricity demand forecast but not the 'reference' and 'high' scenarios. Overall, therefore, based upon the different forecast assumptions, Turkish industrial electricity demand is predicted to be between 90 and 106 TWh in 2015 and between 97 and 148 TWh in 2020. This is somewhat less than the previous forecasts for Turkish industrial electricity demand; Akay and Atak (2006) suggested that demand would be 140.4 TWh in 2015 and Hamzacebi (2007) suggested demand would be 219.2 TWh in 2020 - both of which are somewhat higher than the high case scenario of this study. The difference in forecasts, it is argued, being primarily due to these other studies neglecting the relationship between economic variables, underlying trend, and electricity consumption. ${ }^{9}$

On the other hand, the Kyoto protocol was ratified by Turkish Parliament in February 2009, which is leading to the introduction of legally compulsory commitments for the reduction of greenhouse gases. It is therefore commonly expected there will be a change in Turkish energy policy that might include $\mathrm{CO}_{2}$ taxes and energy efficiency regulations. Regarding this new environment in which markets will operate, determining the industrial electricity demand function might have a significant importance on evaluating new policy implications. Sensible and reliable energy demand forecasts assist in financing and developing the necessary measures for the sustainable economic growth of Turkey. Furthermore, one of the most important issues of $21^{\text {st }}$ century is energy security. Arguably, the policies and strategies cannot be neither assessed nor constructed without sound demand forecasts. Therefore, it is suggested, that the methodology and estimated equation from this research should be taken into account when implementing future Turkish energy policies for energy security, etc.

\footnotetext{
${ }^{9}$ Although also probably reflects the impact of the recession in the late $2000 \mathrm{~s}$.
} 


\section{References:}

Akay D, Atak M. Grey prediction with rolling mechanism for electricity demand forecasting of Turkey. Energy-The International Journal 2006; 32; 1670-1675.

Altinay G, Karagol E. Electricity consumption and economic growth: Evidence from Turkey. Energy Economics 2005; 27; 849-856.

Amarawickma AA, Hunt LC. Electricity demand for Sri Lanka: A time series analysis. Energy 2008; 33, 724-739.

Bakirtas T, Karbuz S and Bildirici M. An econometric analysis of electricity demand in Turkey. METU Studies in Development 2000; 27/1-2 ; 23-34 Ankara Turkey.

Beenstock M, Willcocks P. Energy consumption and economic activity in industrialized countries. Energy Economics 1981; 3; 225-232.

Beenstock M, Willcocks P. Energy and economic activity: a reply to Kouris. Energy Economics ; 1983; 5; 212.

Ceylan H, Ozturk HK. Estimating energy demand of Turkey based on economic indicators using genetic algorithm approach." Energy Conversion and Management 2004; 45; 2525 2537.

Commandeur JF, Koopman SJ. An Introduction to State Space Time Series Analysis. Oxford University Press: Oxford ; 2007

Dimitropoulos J, Hunt LC and Judge G. Estimating Underlying Energy Demand Trends using UK Annual Data, Applied Economics Letters 2005,12, 239-244.

Doornat V, Koopman SJ, Ooms M, Dessertaine A and Collet J. An hourly periodic state space model for modelling French national electricity load. International Journal of Forcasting 2008; 24, 566-587.

Durbin J, Koopman SJ. Time Series Analysis by State Space Methods.Oxford University Press: Oxford; 2001.

Ediger VS, Akar S. ARIMA forecasting of primary energy demand by fuel in Turkey. Energy Policy 2007; 35, 1701-1708.

Ediger VS, Tatlidil H. Forecasting the primary energy demand in Turkey and analysis of cyclic patterns. Energy Conversion and Management 2002; 43; 473-487.

Erbaykal E. Disaggregate Energy Consumption and Economic Growth: Evidence from Turkey. International Research Journal of Finance and Economics 2008 ; 20 ; 172-179.

Erdal G, Erdal H. and Esengun K. The causality between energy consumption and economic growth in Turkey. Energy Policy 2008; 36; 3838-3842. 
Erdogdu E. Electricity Demand analysis using cointegration and ARIMA modelling: a case study of Turkey. Energy Policy 2007; 35; 1129-1146.

Halicioglu, F. Residential Electricity Demand Dynamics in Turkey Energy Economics 2007; $29 ; 199-210$.

Hamzacebi, C. "Forecasting of Turkey's net electricity consumption on sectoral bases." Energy Policy 2007; 35; 2009-2016.

Harvey AC, Shephard N. Structural Time Series Models. In: Maddala GS, Rao CR and Vinod HD (Eds), Handbook of Statistics, Vol. 11 North Holland: Amsterdam; 1993. p 261-302.

Harvey AC. Forecasting, Structural Time Series Models and the Kalman Filter. Cambridge University Press: Cambridge; 1989.

Harvey AC. Trends, cycles and auto regressions. Economic Journal 1997; 107; 192-201.

Harvey AC, Henry S G B, Peters S and Wren-Lewis S. Stochastic trends in dynamic regression models: an application to the employment-output equation. Economic Journal 1986; 96; 975-985.

Harvey AC, Koopman SJ and Shephard N. State Space and Unobserved Component Models: Theory and Applications. Cambridge University Press: Cambridge; 2005.

Harvey AC, Koopman SJ. Forecasting hourly electricity demand using time varying splines. Journal of American Statistical Association 1993; 88-424; 1228-1236

Harvey AC, Scott A. Seasonality in dynamic regression models. Economic Journal 1994; $104 ; 1324-1345$.

Harvey AC, Proietti T. Readings in Unobservable Component Models. Oxford University Press: Oxford ; 2005.

Hepbasli A, Ozalp N. Development of energy efficiency and management implementation in the Turkish industrial sector. Energy Conversion and Management 2003; 44; 231-249.

Hunt LC, Judge G. and Ninomiya Y. Modelling Underlying Energy Demand Trends Chapter 9 in Hunt, LC (Ed) Energy in Competitive Market: Essays in Honour of Colin Robinson. Edward Elgar: UK; 2003a; 140-174

Hunt LC, Judge G. and Ninomiya Y. Underlying trends and seasonality in UK energy demand: a sectoral analysis. Energy Economics 2003b; 25; 93-118.

Hunt LC, Judge G and Ninomiya Y. Modelling Technical Progress: An Application of the Stochastic Trend Model to UK Energy Demand. Surrey Energy Economics Discussion Paper, 2000; SEEDS99. 
Hunt LC, Ninomiya Y. Unravelling Trends and Seasonality: A structural Time Series Analysis of Transport Oil Demand in the UK and Japan. The Energy Journal; 2003, 24-3, 6369.

IEA: International Energy Agency. Energy Balances for OECD Countries retrieved on 04 September 2010 from www.iae.org http://esdsw1.mc.manchester.ac.uk/WDS_IEA/TableViewer/tableView.aspx?ReportId=960.

Jobert T, Karanfil F. Sectoral energy consumption by source and economic growth in Turkey. Energy Policy 2007; 35; 5447-5456.

Karanfil F. Energy consumption and economic growth revisited: Does the size of unrecorded economy matter? Energy Policy 2008; 36; 3029-3035.

Kazgan G. The Economic Crises in Turkey (1929-2001): A comparison of causes and the results. (in Turkish translated by authors) 2002, retrieved on 05 march 2009 from http://kazgan.bilgi.edu.tr/main.asp?p=makaleler

Keleş SM. Electricity demand forecasts and their effects on Turkish economy (In Turkish translated by authors) Republic of Turkey Prime Ministry under Secretariat of Treasury Ankara; 2005 retrieved on 14 March 2009 from http://www.hazder.org.tr/tezler/Mehmet_Sertac_KelesElektrik_Enerjisi_Talep_Tahminleri_ve_Turkiye_Ekonomisine_Etkileri.pdf

Koopman SJ, Harvey AC, Doornik JA and Shephard N. Structural Time Series Analyser and Modeller and Predictor - STAMP Version 8 Econometric Software 2007.

Kouris G. Fuel consumption for road transport in the USA. Energy Economics 1983a; 5; 8999.

Kouris G. Fuel consumption and economic activity in industrialised economies: a note. Energy Economics 1983b; 5; 207-212.

Lise W, Montfort KV. Energy consumption and GDP in Turkey: Is there a co-integration relationship?" Energy Economics 2007; 29; 1166-1178.

McVeigh JC, Mordue, JG. Energy Demand and Planning. The Watt Committee on Energy: UK; 1999.

Ozturk HK, Ceylan H, Canyurt OE and Hepbasli A. Electricity estimation using genetic algorithm approach: a case study of Turkey. Energy 2005; 30; 1003-1012.

Soytas U, Sari R. The relationship between energy and production: Evidence from Turkish manufacturing industry. Energy Economics 2007; 29; 1151-1165.

Taymaz E, and Yilmaz K. Integration with the global economy the case of Turkish Automobile and consumer electronics Industries. Commission on Growth and Development 
Workshop 12-14 April 2007 Washington; retrieved on 22 March 2009 from http://www.ku.edu.tr/ku/images/EAF/eaf_wp_0801.pdf

World Bank. World Development Indicators 2010 retrieved on 05 September 2010 from www.worldbank.org 

Note:

This paper may not be quoted or reproduced without permission

Surrey Energy Economics Centre (SEEC) Department of Economics University of Surrey

Guildford Surrey GU2 7XH 
SuRReY

ENERGY $_{\text {Net }}$

Economics

Discussion paper

$\mathbf{S}_{\text {ERIES }}$

\title{
For further information about SEEC please go to:
}

\author{
www.seec.surrey.ac.uk
}

